\title{
Why We Need to be Investigated
}

Mr. Metcalf is director, Harvard University Library.

TFE IS FULL OF problems-and would be a $\mathcal{L}$ pretty dull affair if it were not. If libraries and library work were not full of problems, the lives of most of us here would be less interesting than they are. The problems of research libraries-and particularly the financial implications that are to be found in most of these problemsare so interesting that the Association of American Universities hopes to study them during the coming months through a special commission which it will sponsor.

The large research libraries, in other words, are going to be investigated by the university presidents, and this should help to make life interesting for research librarians. The idea that there ought to be such an investigation originated with librarians. It was their own idea, so it would seem that the librarians are not too worried over what will be found out about them; but you can never be quite sure, when an investigation starts, just how it will end. There would be no point to one anyway if the answers were known to start with.

As a matter of fact, we are not even sure that we know the right questions, let alone the answers. In order to give the investigators some help in deciding just what they ought to investigate, the Association of $\mathrm{Re}$ search Libraries is sponsoring a conference that will meet October 29-3I at Allerton House (which belongs to the University of Illinois) near Monticello, Illinois. Those

\footnotetext{
* Paper presented at the general session of ACRL, Minneapolis, Minn., June 22, 1954.
}

who meet there will be the librarians of libraries belonging to the ARL, presidents of universities belonging to the $\mathrm{AAU}$, and professors (not more than one per university) from the same institutions.

There are only forty-five libraries that belong to the ARL. The librarians here who come from smaller institutions may wonder if they have any real stake in the conference and study that I have mentioned. Their problems may seem different. Their libraries are not going to be investigated, at least not directly. But I should not be giving this talk to this group if I were not convinced that we are all in the same boat. There are two chief reasons: the first is that all of our libraries are growing, and growth seems to be the underlying cause of nearly all the financial problems that need to be studied; the second reason is that all of our libraries serve scholars, and that each must turn to others for help in supplying some of the materials that scholars need. If the largest research libraries can be strengthened, it will help scholars everywhere; if they grow weaker, it will hurt. If new developments in cooperation result from study of research library problems, all of us will be affected.

Growth is certainly not bad in itself. But college and university libraries are parts of the institutions to which they belong, and it is obvious that complications will arise if they grow-at least if the cost of maintaining them grows-more rapidly than the colleges and universities themselves. We know, as Fremont Rider, Dean Ridenour of the University of Illinois, and others have told us during recent years, that research 
libraries have doubled in size every sixteen to twenty years; and it is obvious that this exponential or geometric rate of increase in holdings cannot continue indefinitely. It is in fact slowing down, at least in our largest libraries.

But the ratio of library expenditures to total expenditures of the college or university is the heart of the matter, and there are many reasons, it seems to me, why libraries must tend to take more and more of the total if they go on as in the past. Libraries grow cumulatively; they acquire but do not discard. A university admits students and graduates them, unless they drop by the wayside; it can stabilize its enrolment. Professors come and professors go; the faculty grows relatively slowly in size if the student body does not increase. But the library continues to grow whether or not the student body and faculty grow; an old book is not discarded because a new one has been bought. More and more space is needed. Each volume that is added costs something for storage and service every year as long as it remains in the collection.

Libraries, moreover, are not like factories. Mass production is a means of cutting unit costs in industry; large plants are built because they can be more efficient than small ones. In a library, on the contrary, unit costs have tended to increase as the collection grows, and so far we have been unable to change this tendency. It is more expensive to add a book when you have a million volumes than when you have a hundred thousand. You have to describe it in greater detail to distinguish it from others. You have to use a more complicated subject heading for it. You have to file the cards in a catalog that is ten times as large. The stacks are larger, so you have to go further to get the book and to put it back when it is returned. The charge file is more difficult to handle.
If a library is improved - and growth is improvement--it is also used more heavily. More books are borrowed. If it develops outstanding collections, more and more visitors come from other campuses to use it, and more and more requests for interlibrary loans are received.

One other major reason for rising library costs ought to be mentioned. In many institutions salaries for librarians have been increasing more rapidly than salaries for professors, but they are still lower than they ought to be, and further increases must and should be expected. This problem is not one of those entailed by growth, but it is one that must be faced by all our libraries, large and small.

It ought to be added that in many institutions unusual circumstances during recent years have prevented library expenditures from rising more rapidly than the total college or university budget. The number of students increased rapidly after the war, and a doubled undergraduate enrolment, while it involves library expenditures for public services and for duplication of books assigned for reading, does not affect the library as much as some other parts of the institution. Likewise, great university building programs during the postwar years have tended to conceal the growing space needs of libraries. The point is that other parts of the university can halt or greatly retard their rate of growth as a "boom" period of this sort comes to an end, but the library will continue its growth unless it reduces its services drastically. Greatly extended interlibrary cooperation, some of us hope, may offer an alternative.

I have said that I think we are all in the same boat, and that one reason for this is that all our libraries are growing, butthough I am well aware that this is dangerous ground-I want to add that I think the growth problem ought to be less serious 
for the college than for the university library. I do not want to propose any absolute limit for the size of libraries in liberal arts or teachers' colleges. Perhaps such a library ought to discard an out-of-date monograph every time, or nearly every time, it adds a new one, but even so, serial collections would continue to grow. A collection for undergraduates such as the Lamont Library at Harvard can be stabilized in size, but even this is not easy, though Lamont is less than a minute away from the main collection of the university. The difficulties are much greater when members of a college faculty must depend on the library, for they will never be satisfied, however large it is.

The college ought to support a library that will take care of the normal needs of its student, but I believe that college professors will have to rely more and more during the years ahead on larger libraries in the area for research materials. Each of our small liberal arts colleges cannot hope to build up a great collection of books, and it would be very wasteful if each tried to do so. Cooperation, as I have said already, is not something that affects only members of the ARL.

Sooner or later, indeed, cooperation may entail developments that will not be welcomed by the smaller libraries. If we come to realize more and more clearly that the nation's library resources are a reservoir that serves the whole nation, and if the largest libraries deliberately buy books that are needed by that national reservoir rather than by the particular institution that buys them, it seems likely that the question of fees will arise. I should describe this as inevitable if it were not possible that government or industry will assume some of the burden of providing this type of national library service.

I have spoken of fees before, and it is not a popular thing to do. I have done so because I prefer, whenever I can, to face unpleasant possibilities while there is still time to discuss them fully and reach unhurried decisions. We may not be able to avoid fees for interlibrary services, but, by considering them now, we may at least work out a more sensible plan than if we wait until financial pressure forces libraries to act hastily and independently.

This theory that it is better to face problems while they are still problems, rather than to wait until they become crises, is back of the Monticello Conference and of the proposal that it be followed by an investigation. If growth is going to bring pressure on our budgets, it may be highly desirable to start examining library expenditures now, and to get professors and university presidents to examine them with us. If the scholars and administrators produce any new and practicable ideas on how to save money, that will be fine; if they do not, at least they will have been educated a good deal in the process.

The Monticello Conference, therefore, will start by considering where we spend most of our money and why. Space for books, for readers, and for staff is a major item, and too many of our present library buildings are so poorly designed that they are more expensive to maintain than they ought to be. Continuing growth means that we all face the necessity sooner or later for planning new buildings or additions; wise planning will save money in construction, and will save even more on upkeep costs throughout the life of the structure.

Our acquisition programs obviously call for study by our faculties, and can hardly be effective unless they are understood by the professors to whom we must turn for help in book selection. Librarians are well aware that the purchase price of a volume is only a fraction of its total cost to the library, 
which includes acquisition, cataloging, and storage space; the non-librarians who recommend books for purchase ought to know this, too. Binding policies, incidentally, may also call for reconsideration, for it is extravagant at present prices to invest in first class binding for a book that may be used only once or twice in a decade.

Cataloging costs are likely to shock the layman, and they certainly do not make the library administrator happy. Few of us are satisfied with what we have accomplished either in simplification or in cooperative cataloging, and few of us feel sure that our catalogs might not be better designed to serve those who use them. It would be both cruel and impracticable to staff our catalog departments with people who dislike cataloging, but we suspect that those who choose to become catalogers frequently have a tendency toward perfectionism that is not helpful in keeping costs down.

In public services, as in cataloging, the professors who use our libraries and the presidents who pass on budgets ought to consider whether, in view of the costs involved, we are doing more or less than we ought. If further research assistance is to be given to professors, it will be expensive; if we need only give students and faculty a minimum of advice on how to help themselves, some of us can save money.

At every point in any consideration of library expenditures, this question of service standards arises. If we were to close our stacks and shelve books by size we could save a great deal of space. If we can discard books or store them cheaply, we may save more than might be expected. For example, if a large library, by discarding or storage, can postpone the construction of a new $\$$ Io,ooo,ooo building for five years, it can save the interest on this sum, amounting to $\$ 2,500,000$, which would go a long way to improve the library in other respects.
Those who advocate storage or discarding ought not, of course, to underestimate the cost of withdrawing books from the collection or the difficulties of selecting material that is to be discarded or stored. It is more expensive to change the records for the average monograph than to store it for several years. It is not easy to get members of the faculty to agree on volumes that need not be kept at all or on those that may be stored at a distance from the main collection.

Storage can be provided individually, but greater savings are promised by cooperative projects, such as the Hampshire and Midwest Inter-Library Centers, that eliminate duplicates. This brings us back to cooperation and suggests another reason for the Monticello Conference. The individual librarian can attempt to educate his faculty and his president by encouraging them to ponder library problems of the sort that have been suggested. Librarians as a group can meet and work together on cooperative plans, and their accomplishments along these lines have been considerable. But librarians alone cannot commit their institutions to participation in interlibrary centers or to a division of collecting fields that would bring real savings; they are helpless when it comes to a division of fields of instruction and research between universities. It seems doubtful that they can go much further with cooperative plans on a national scale unless their faculties and presidents understand and support these plans. At Monticello, for the first time, there will be a discussion of national library cooperation by representatives of all three of the groups most directly concerned.

I am not optimistic enough to predict that all — or any — of the problems of cooperation are going to be solved this year at Monticello or soon afterward when the AAU's study is made. The Midwest is engaged in an experiment that all of us shall want to 
observe closely, but it will be some time before everyone is convinced either that the answer has been found or that some alternative is preferable to storage in a regional center. Even if the major university libraries of the Midwest prove to be willing and able to build up a great regional library in Chicago, it may not follow that Harvard, Yale, Columbia, and other endowed institutions in the Northeast will do likewise for their region.

Another major field for cooperative effort is microreproduction. We should not overlook the fact that, except in the case of newspapers, it costs more to film a volume than to store the original, and that the reproduction is less satisfactory in many ways. If copies of the original can be eliminated from several libraries, storage costs can of course be reduced by filming. Much more filming will have to be done, if only to preserve the text of hundreds of thousands of volumes printed on wood-pulp paper that will not be with us much longer. We can take pride in the microfilm and microprint projects that libraries have undertaken or supported, but are we sure that a more economical basis would not have been practicable? Microfilming projects have been operated like publishing ventures; as many libraries as possible have been induced to subscribe to each series in order to bring down the cost per subscriber. Some materials are needed in so many collections that publication of this kind is advisable; but in many other cases it seems clear that research libraries as a group would save money if, in addition to the master negative, only one or two positives were produced for loan or rental. The complications, of course, arise when you try to decide how much to charge when one reel out of a great set is wanted on loan by a library that did not help to finance the project. Here, as at so many points in cooperation, life is greatly simplified if some outside source, such as a government or a foundation, will provide the money and make it unnecessary for the large research libraries to tax themselves for cooperative enterprises.

It is true that sixty libraries are now "taxing" their book funds to support the Farmington Plan and are not charging non-participants for use of the materials they acquire under it. This first step toward nationwide specialization or division of fields in collecting encourages us to hope that further steps will follow. Serials and non-trade publications remain to be tackled. However, even if the Farmington Plan were "complete"if it were bringing to this country one copy of every publication that ought to be heremuch more would still remain to be done in the field of specialization.

If specialization is going to help us reduce the rate at which our libraries grow, and thus is going to support a major attack on the problem of rising costs, it seems clear that colleges and universities, not just their libraries, are going to have to specialize. Each of us must continue to buy books on almost every subject under the sun as long as each of our institutions is sponsoring instruction and research on almost every subject. If the Monticello Conference can do anything to start us toward a solution of this problem, it will earn itself a very honorable place in library history.

Having first discussed what libraries do for members of a university and how much they cost, and having then taken a look at the possibilities of cooperation and specialization, the Conference will devote a session to the outlook for library financing. I shall not venture to predict what the crystal ball will reveal at this session, which will be followed by a final one at which there will be an attempt to identify the problems that seem most deserving of further study during

(Continued on page 392) 
Book publishing, per se, is a tough business. The per unit cost steadily mounts. No single element in the cost of manufacture reveals any other tendency. The cost of composition, paper, binding, jackets and even prospectuses, follow the trend. In a small business, also, higher costs cannot be passed along to the consumer. "Publishing and certain specialized textile operations," states an economist, "cannot cope with inflation." They are examples of "the sort of business which finds itself caught between an inelastic selling price and costs it cannot control." The "break-even point" is too high. The Library has learned that no one will pay $\$ 7.00$ for a trade book, no matter how authoritative and scholarly. Small businesses, too, find it impossible to cut overhead. In our case one person, certainly, is needed to take orders over the phone, to mail out books, to call on dealers, to maintain the records, and to correspind occasionally with anxious authors! Moreover, books cannot be distributed without paying the postage fee, and certainly enough advertising must be done to notify potential customers that a book has been published.

The outlet for hardbound books is diminishing. In I95 I there were 3,500 bookstores of some reputation. 'Today there are fewer than 3,000. The "soft-bounds," marketed in drugstores, grocery stores, stations, etc. have taken a hard toll of the retail bookman.
At best, then, our enterprise is one jump ahead of the sheriff.

On the other hand, the Huntington Library is a research library with rare book and manuscript resources that grow continually, and with a large following of scholars in the humanities. It is inconceivable that the Library should not make an effort to publish the results of the best work done here. To be sure, a few men are prominent enough to receive the backing of commercial publishers and a few others can count on their university presses, but the large majority (among them many promising young men) have only the discouraging prospect of publication by using their savings.

The heart of the matter rests in the fact that the Huntington Library has managed to publish the best of the work of its readers regardless of cost. To paraphrase Norman Cousins, book publishing is essential to the national culture, and book publishers, large and small, are custodians, in a sense, of infinitely valuable literary properties, the future protectors of talent yet to be developed. This period of adventuring, therefore, will continue so long as talented scholars are willing, at such personal sacrifices to them, to ponder and appraise the cultural heritage of the English-speaking people. Publishing by the Huntington Library fosters this talent.

\section{Why We Need to be Investigated}

\section{(Continued from page 387)}

the investigation that will start soon afterwards. I shall be surprised if the problems are not plentiful.

I shall be surprised also if it does not do us good to be investigated. I think the investigators will benefit too. We do not want to supply more books or more services than are needed. If there are non-essentials that can be eliminated, we shall be glad to know of them. We shall welcome help in solving our problems, and we can feel sure that professors and presidents who understand these problems will not advocate solutions-or budgets-that will ruin our libraries, which after all are theirs as much as ours. 